\title{
ANALISIS FAKTOR-FAKTOR YANG DIPERTIMBANGKAN SISWA DALAM PENGAMBILAN KEPUTUSAN SEKOLAH DI SMK NASIONAL MOJOSARI
}

\author{
M. Syamsul Hidayat ${ }^{1}$ Eny Setyariningsih $^{2}$ \\ ${ }^{1,2}$ Fakultas ekonomi, Universitas Islam Majapahit \\ Email $^{1}$ : syamshidayat@gmail.com \\ Email $^{2}$ : eny.se888@gmail.com
}

\begin{abstract}
The purpose of this study was to determine what factors influenced students choosing schools at the National Vocational School in Mojosari. With the limitation of the problem in this study, the students who attend the Mojosari National Vocational Schools in grades 2 and 3. Vocational High Schools (Vocational High Schools) are a formal educational institution that organizes vocational education from secondary/junior high school. The method in this research uses quantitative methods. The population in this study was all students in grade 2 and 3 who attended the National Vocational School in Mojosari. To determine the sample using an opinion (Maholtra, 2006:291) that is 4 or 5 times the number of variables known in this study the variables are $42 \times 4=168$, so the number of samples from this study amounted to 168 respondents. The technique used is proportionate stratified random sampling, this technique is used for populations that have proportional and non-homogeneous stratified members/elements (Sugiyono, 2016:82). Sources of data in this study are primary, secondary and documentation data. For the results of factor analysis, the $K M O$ (Kaisser-Meyer-Olkin) measure of sampling adequacy of 0.706 is greater than 0.5 and there are 42 variables whose values are above 0.5 . For the factors formed there are 15 factors out of 42 variables. Of the 15 factors formed, the most influential were school product factors with a variance value of 15,885.
\end{abstract}

Keywords : Factor Analysis, Student Decision Making.

\begin{abstract}
Abstrak
Tujuan penelitian ini adalah untuk mengetahui faktor-faktor apa saja yang dipertimbangkan siswa memilih sekolah di SMK Nasional Mojosari. Dengan batasan masalah dalam penelitian ini yaitu siswa yang bersekolah di SMK Nasional Mojosari kelas 2 dan 3. SMK (sekolah menengah kejuruan) merupakan suatu lembaga pendidikan formal yang menyelenggarakan pendidikan kejuruan dari lanjutan SMP/MTS. Metode dalam peneliian ini menggunakan metode kuantitatif. Populasi didalam penelitian ini seluruh siswa kelas 2 dan 3 yang bersekolah di SMK Nasional Mojosari. Untuk menentukan sampel menggunakan pendapat (Maholtra, 2006:291) yaitu 4 atau 5 kali dari jumlah variabel yang diketahui dalam penelitian ini variabelnya berjumlah $42 \times 4=168$, jadi jumlah sampel dari penelitian ini sebesar 168 responden. Teknik yang digunakan adalah proportionate stratified random sampling yaitu teknik ini digunakan untuk
\end{abstract}


populasi yang mempunyai anggota/unsur berstrata secara proporsional dan tidak homogen dalam (Sugiyono, 2016:82). Sumber data dalam penelitian ini adalah data primer, sekunder dan dokumentasi. Untuk hasil analisis faktor menunjukan nilai KMO (Kaisser-Meyer-Olkin) measure of sampling adequacy sebesar 0,706 nilai ini lebih besar dari 0,5 dan terdapat 42 variabel yang nilainya diatas 0,5. Untuk faktor yang terbentuk terdapat 15 faktor dari 42 variabel. Dari 15 faktor terbentuk yang paling berbengaruh adalah faktor produk sekolah dengan nilai varian 15,885 .

\section{Kata Kunci : Analisis Faktor, Pengambilan Keputusan Siswa.}

\section{PENDAHULUAN}

Perkembangan zaman yang semakin maju, kebutuhan ilmu pengetahuan atau wawasan dan teknologi yang semakin canggih membuat masyarakat sadar akan pentingnya suatu pendidikan, pendidikan sangat penting untuk menunjang kelangsungan hidup. Beberapa progam pemerintah di Indonesia yang mewajibkan warga negaranya wajib belajar sampai lulus SMA/SMK. SMK (Sekolah Menengah Kejuruan) adalah suatu lembaga pendidikan formal yang menyelenggarakan pendidikan kejuruan dari lanjutan SMP/MTS. Sekolah merupakan tempat untuk belajar, mengenyam pedidikan untuk menjadi orang yang pandai dan lebih baik lagi dari sebelumnya. Keberhasilan sekolah dapat dilihat dari siswanya yang berkompeten pada saat keluar dari sekolah dan siswa bisa bersaing dengan lulusan dari sekolah lainnya.

Banyaknya sekolah disekitar SMK Nasional Mojosari membuat persaingan sekolah semakin ketat seperti SMK Raden Rahmat, SMA Negeri Mojosari, SMK PGRI, dll. Persaingan tidak hanya ada di dunia jual-beli barang saja melainkan jasa juga mengalami persaingan yang ketat. Hal ini membuat setiap sekolah berlomba mendapatkan siswa sebanyak-banyaknya. Di sekolah SMK Nasional Mojosari banyak jurusan yang bisa di ambil oleh para siswa baru. Pada tahun 1996 pemerintah menyederhanakan satu nama yaitu STM Nasional Mojosari berubah menjadi SMK Nasional Mojosari. SMK Nasional Mojosari mempunyai beragam prestasi yang diraih oleh siswa seperti karate (juara 1 Sekabupaten Tulungganggung), sepak bola (juara 4 Se SMA/SMK Se Jawa Timur dan Best Player).

Dari banyaknya faktor yang dipakai peneliti untuk melakukan penelitian berdasarkan Bauran pemasaran terdiri dari : Produk (product), Harga (price), Tempat (place), Promosi (promotion), Proses (procces), Orang (people), Sarana fisik (physical evidence) dan Perilaku konsumen terdiri dari : Budaya, Kelompok, Keluarga, Pendapatan keluarga, Kepribadian dan konsep diri, Motivasi, Persepsi, Keyakinan dan sikap yang mempengaruhi keputusan siswa memilih sekolah di SMK Nasional Mojosari.

Sekolah SMK Nasional Mojosari juga ingin meningkatkan jumlah siswanya. Agar siswa yang sekolah di SMK Nasional Mojosari semakin banyak kedepannya. Dari latarbelakang di atas dan peneliti dulu pernah sekolah di SMK Nasional Mojosari. Peneliti memutuskan melakukan penelitian dengan judul Analisis Faktor-Faktor Yang Mempengaruhi Siswa Memilih Sekolah Di Smk Nasional Mojosari. 
Tujuan penelitian ini adalah untuk mengetahui faktor-faktor apa saja yang mempengaruhi siswa sekolah di SMK Nsional Mojosari.

\section{KAJIAN PUSTAKA}

\section{Pemasaran}

Asal kata pemasaraan berasal darai kata pasar yaitu market. Apa yang dipasarkan ialah jasa dan barang dalam (Buchari Alma, 2013:01).

1. Jasa

Jasa merupakan manfaat atau aktivitas yang dapat dilakukan/ditawarkan oleh satu pihak ke pihak lainnya dan tidak mengakibatkan perpindahan kepemilikan dalam (Ratih Hurriyati, 2015:47).

2. Karakteristik jasa

Menurut Bitner dkk (1993), serta Tadepalli dan Hayes (2000) dikutip (David Wijaya, 2016:02) karakteristik jasa ada 5 yaitu tidak berwujud (intangibility), tidak terpisahkan (inseperibility), beraneka ragam (variability), tidak tahan lama (perishability), kepemilikan (ownership).

\section{Bauran pemasaran}

Merupakan suatu alat atau elemen pemasaran yang berada dalam suatu perusahaan, dimana perusahaan mampu mengendalikannya agar dapat mempengaruhi respon pasar sasaran dalam (Tengku Firli Musfar, 2018:01).

\section{a. Produk (product)}

Produk jasa merupakan suatu kinerja penampilan, lebih dapat dirasakan daripada dimiliki, cepat hilang dan tidak berwujud, serta pelanggan lebih dapat berpartisipasi aktif dalam proses mengkonsumsi jasa tersebut dalam (Ratih Hurriyati, 2015:50).

b. Harga (price)

Harga (price) adalah uang yang dinyatakan dengan nilai suatu barang dalam (Buchari Alma, 2013:169).

c. Tempat (place)

Place diartikan sebagai tempat pelayanan jasa dalam (Ratih Hurriyati, 2015:55)

\section{d. Promosi (promotion)}

Promosi adalah suatu bentuk komunikasi pemasaran. Yang merupakan tindakan/aktivitas pemasaran yang berusaha menyebarkan informasi, membujuk/mempengaruhi dan/atau mengingatkan pasar sasaran atas perusahaan dan produknya agar bersedia membeli, menerima, dan loyal pada produk yang ditawarkan perusahaan yang bersangkutan dalam (Ratih Hurriyati, 2015:58).

e. Orang (people)

Orang (people) adalah seluruh atau semua pelaku yang memainkan peranan dalam penyajian jasa sehingga dapat mempengaruhi persepsi pembeli (diusulkan Zeithaml dan Bitner (2000:19) dikutip (Ratih Hurriyati, 2015:62). 


\section{f. Sarana fisik (physical evidence)}

Sarana fisik ini merupakan suatu hal yang secara nyata turut mempengaruhi keputusan konsumen untuk mengunakan produk jasa yang ditawarkan dan membelinya (diusulkan Zeithaml dan Bitner (2000:20) dikutip (Ratih Hurriyati, 2015:64).

\section{g. Proses (procces)}

Proses adalah mekanisme, semua prosedur aktual, dan aliran aktivitas yang digunakan untuk menyampaikan jasa (diusulkan Zeithaml dan Bitner (2000) dikutip (Ratih Hurriyati, 2015:64).

\section{Perilaku konsumen}

Menurut schiffman dan kanuk (2004) dikutip (Tengku Dan Hapsari, 2014:1.3), perilaku konsumen didefinisikan sebagai berikut. Istilah perilaku konsumen diartikan sebagai perilaku yang diperlihatkan oleh konsumen dalam mencari, membeli, menggunakan, menghabiskan produk, mengevaluasi, dan jasa yang mereka harapkan akan memuaskan kebutuhan mereka.

\section{a) Faktor kebudayaan}

- Budaya

Budaya adalah penyebab paling mendasar dari keinginan dan tingkah laku seseorang dalam (Ratih Hurriyati, 2015:94).

- Sub budaya

Setiap budaya terdiri dari beberapa subbudaya yang lebih kecil, atau kelompok orang yang mempunyai system nilai sama berdasarkan pada situasi dan pengalaman hidup. Subbudaya termasuk wilayah geografi, nasionalitas, ras, dan agama dalam (Ratih Hurriyati, 2015:95).

b) Kelas sosial

Kelas sosial adalah divisi masyarakat yang relatif teratur dan permanen dengan para anggotanya menganut nilai-nilai, tingkah laku yang serupa, dan minat dalam (Ratih Hurriyati, 2015:95).

c) Faktor sosial

- Kelompok

Kelompok keanggotaan : Kelompok yang mempunyai pengaruh langsung dan seseorang yang menjadi anggotanya disebut kelompok keanggotaan dalam (Ratih Hurriyati, 2015:96).

Kelompok acuan : Kelompok acuan berfungsi sebagai titik perbandingan atau acuan langsung (tatap muka) atau tidak langsung dalam membentuk sikap atau tingkah laku seseorang dalam (Ratih Hurriyati, 2015:96).

- Keluarga

Keluarga adalah organisasi yang telah diteliti secara mendalam atau organisasi pembelian konsumen yang paling penting dalam masyarakat dalam (Ratih Hurriyati, 2015:97).

- Peran dan status

Peran terdiri dari tindakan aktivitas yang diharapkan dilakukan seseorang menurut orang-orang yang ada di lingkungan sekitarnya. 
Setiap peran membawa status yang mencerminkan penghargaan yang diberikan oleh masyarakat. Orang seringkali memilih produk yang menunjukkan statusnya dalam masyarakat dalam (Ratih Hurriyati, 2015:97).

d) Faktor pribadi

- Umur dan tahan daur hidup

Orang merubah jasa dan barang yang mereka beli selama masa hidupnya. Selera akan pakaian, makanan, perabot, dan rekreasi seringkali berhubungan dengan umur. Membeli juga dibentuk oleh tahap daur hidup keluarga tahap-tahap yang mungkin dilalui oleh keluarga sesuai dengan kedewasaannya dalam (Ratih Hurriyati, 2015:98).

- Pekerjaan

Pekerjaan seseorang mempengaruhi jasa dan barang yang dibelinya. Pekerja kantor membeli lebih banyak jas dan dasi sedangkan pekerja kasar cenderung membeli lebih banyak pakaian untuk bekerja dalam (Ratih Hurriyati, 2015:99).

- Situasi ekonomi

Situasi ekonomi akan mempengaruhi pilihan produk. Pemasar produk yang peka terhadap pendapatan mengamati kecenderungan dalam tingkat minat, tabungan dan pendapatan pribadi dalam (Ratih Hurriyati, 2015:99).

- Gaya hidup

Gaya hidup adalah pola kehidupan seseorang yang diwujudkan dalam psikografiknya dalam (Ratih Hurriyati, 2015:99).

- Kepribadian dan konsep diri

Kepribadian biasanya diuraikan dalam arti sifat-sifat seperti keagresifan , cara menyesuaikan diri dan rasa percaya diri. Dasar pemikiran konsep diri adalah bahwa apa yang dimiliki seseorang memberi kontribusi dan mencerminkan identitas mereka artinya kami adalah apa yang menjadi milik kami jadi agar dapat memahami tingkah laku konsumen, pertama-tama pemasar harus memahami hubungan antara konsep diri konsumen dan miliknya dalam (Ratih Hurriyati, 2015:100). Kepribadian adalah merupakan (pola perilaku) yang konsisten terhadap stimulasi lingkungan dan berlaku lama menurut engel (2001:367) dikutip (Ratih Hurryati, 2015:89).

e) Faktor psikologis

- Motivasi

Motif (atau dorongan) adalah kebutuhan yang cukup menekan untuk mengarahkan seseorang mencari kepuasan dalam (Ratih Hurriyati, 2015:101).

- Persepsi

Persepsi adalah proses yang dilalui orang dalam mengorganisasikan, memilih, dan menginterprestasikan informasi 
guna membentuk gambaran berarti dunia dalam (Ratih Hurriyati, 2015:101).

- Pengetahuan

Pengetahuan adalah suatu ingatan konsumen yang menyimpan sebuah informasi (diusulkan Engel, 2001:313) dikutip (Ratih Hurriyati, 2015:84).

- Keyakinan dan sikap

Keyakinan adalah suatu buah pemikiran yang deskriptif yang dimiliki seseorang mengenai sesuatu. Sikap menguraikan perasaan, evaluasi, kecenderungan dari seseorang terhadap suatu obyek atau ide yang relatif konsisten dalam (Ratih Hurriyati, 2015:102).

\section{Keputusan pembelian}

Suatu keputusan adalah pilihan seleksi dari dua alternatif atau lebih dalam (Tengku Ezni Balqiah Hapsari Setyowardhani, 2014:8.4). Keputusan pembelian adalah aktivitas atau tindakan dari konsumen untuk membeli produk baik itu berupa barang ataupun berupa jasa dalam (Kotler dan Amstrong, 2014:158).

\section{Proses pengambilan keputusan}

Proses tahapan-tahapan pengambilan keputusan dalam (Lupiyadi, 2014:2.4): pengenalan kebutuhan, pencarian informasi, evaluasi alternatif, keputusan pembelian dan perilaku setelah pembelian.

\section{KERANGKA PIKIR PENELITIAN}

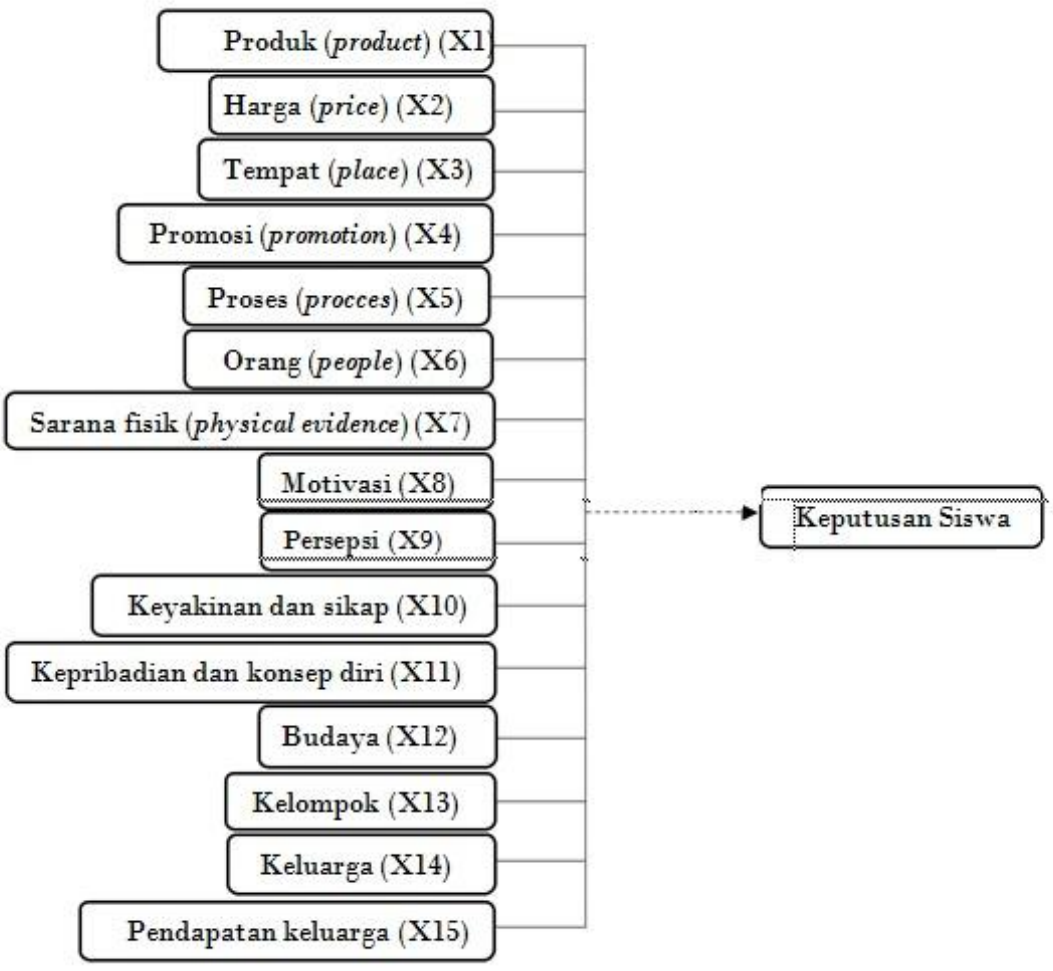

Gambar 1. Kerangka Pikir Penelitian 


\section{METODE PENELITIAN}

\section{Desain Penelitian}

2. Pendekatan kuantitatif yang dipakai dalam penelitian ini dan desainnya exploratory research yaitu menggali data dari responden, mengkaji variabel yang diteliti dan data yang terkumpul diharapkan dapat menjelaskan obyek yang diteliti. Sumber data penelitian ini adalah sumber data primer dan sekunder. Untuk pengumpulan data menggunakan metode wawancara, angket kuesioner dan dokumentasi. Lokasi penelitian ini terletak di JL. Pemuda VI A/ 9 Mojosari Mojokerto Dusun Tuwiri Rt 01 Rw 09 Desa/Kelurahan Seduri Kecamatan Mojosari.

3. Populasi dan Sampel

4. Populasi penelitian ini adalah seluruh kelas 2 dan 3 yang dijadikan responden penelitian yang berjumlah 184 responden. Sampel adalah jumlah yang mewakili dari populasi tersebut. Pengambilan sampel yang dipakai dalam penelitian ini 4 kali jumlah variabel yang diketahui variabel berjumlah 42x4=168, jadi jumlah sampel yang dipakai berjumlah 168 responden.

\section{Instrumen Penelitian}

a) Uji validitas : Uji validitas dipakai untuk mengukur valid tidaknya kuesioner atau sahnya kuesioner. Suatu kuesioner dikatakan sah atau valid jika pertanyaan pada kuesioner mampu untuk mengungkapkan sesuatu yang akan diukur oleh kuesioner tersebut dalam (Imam Ghozali, 2016:52). Untuk uji validitas dalam penelitian ini menggunakan korelasi bivariate untuk membandingkan $r$ tabel dengan $\mathrm{r}$ hitung taraf signifikannya $5 \%$ atau 0,05 . Untuk menguji kuesioner menggunakan dari jumlah responden sebanyak 52-2=50 yang $\mathrm{r}$ tabelnya sebesar 0,273.

b) Uji realibilitas : Realibilitas adalah suatu alat yang dipakai mengukur kuesioner merupakan indikator dari variabel atau konstruk dalam (Imam Ghozali, 2016:47). Untuk uji realibilitas dalam penelitian ini menggunakan pengukuran sekali saja dengan melihat nilai cronbach Alpha $(\alpha)>0,70$ suatu konstruk dinyatakan reliable atau konsisten.

\section{Analisis Data}

Analisis faktor merupakan prosedur analisis yang digunakan untuk data summarization (meringkas) atau reduction (mengurangi), atau mereduksi dimensi dalam (Imam Gunawan, 2017:289). Menurut Fructher (1994) yang dikutip dari Gunawan (2016:293) berbagai langkah yang dilakukan dalam analisis faktor yaitu (1) menyunsun atau membuat matriks korelasi antar masing-masing subfaktor. Masing-masing subfaktor tersebut dalam penelitian adalah penjumlahan dari item-item sehingga merupakan jumlah keseluruhan dari subfaktor. Selanjutnya dilakukan pengujian measure of sampling adequacy dengan Kaiser Meyer Olkin (KMO). Uji KMO bertujuan (1) untuk mengetahui apakah semua data yang telah diambil telah cukup untuk di faktorkan atau dilanjutkan; (2) untuk menentukan faktor atau ekstraksi faktor dengan menggunakan principle component 
analysis, karena dapat mengambil varians sebanyak-banyaknya; (3) untuk menghentikan ekstraksi faktor menggunakan tolak ukur eigen value lebih dari 1; dan (4) melakukan rotasi dari faktor yang telah terbentuk. Tujuan dari rotasi untuk memudahkan dalam interprestasi atau pengelompokkan.

\section{HASIL DAN PEMBAHASAN}

1. Hasil Uji Validitas dan Realibilitas

a) Uji Validitas : Hasil uji validitas penelitian ini menunjukkan angka $r$ hitung lebih besar dari $r$ tabel dengan nilai $r$ tabel sebesar 0,273, nilai signifikannya semua angka dibawah 0,05 dan pengolahan angka di SPSS IBM 25 semua data diatas $\mathrm{r}$ tabel artinya kuesioner dikatakan sah atau valid.

b) Uji Realibilitas : hasil uji realibilitas menunjukkan angka 0,916 yang diatas 0,7 artinya kuesioner reliable atau konsisten.

\section{Analisis Data}

a) Menyunsun atau membuat matriks korelasi antar masingmasing subfaktor.

Masing-masing subfaktor dalam penelitian ini adalah penjumlahan dari item-item pertanyaan yang sudah dibuat atau sudah disusun oleh peneliti kemudian dilakukakan pengujian measure of sampling adequacy dengan KMO (Kaiser Meyer Olkin).

Tabel 3. Pengujian KMO and Bartlett's Test

\begin{tabular}{|ll|l|l|}
\hline \multicolumn{3}{|c|}{ KMO and Bartlett's Test } \\
\hline $\begin{array}{l}\text { Kaiser-Meyer-Olkin } \\
\text { Adequacy. }\end{array}$ & Measure of Sampling & 706 \\
\hline $\begin{array}{l}\text { Bartlett's } \\
\text { Sphericity }\end{array}$ & Test & Approx. Chi-Square & 1893.627 \\
\cline { 2 - 3 } & df & 861 \\
\cline { 2 - 3 } & Sig. & .000 \\
\hline
\end{tabular}

Dari tabel diatas menunjukkan nilai KMO (Kaisser-Meyer-Olkin) measure of sampling adequacy sebesar 0,706 nilai ini lebih besar dari 0,5 dan nilai bartlett's tes of sphericity dengan nilai chi-square sebesar 1893.627 dan signifikannya sebesar 0,000. Artinya anasis faktor ini bisa dilanjutkan

b) Menentukan faktor atau dilanjutkan ekstraksi faktor dengan menggunakan principle component analysis.

Untuk menentukan faktor atau ekstraksi di menu SPSS di kotak extraction peniliti memilih metode principle component analysis. Metode ini paling sederhana banyak digunakan untuk melakukan ekstrasi faktor dan untuk menghentikan ekstraksi ini menggunakan tolak ukur eiginvalue yaitu lebih besar dari satu (>1).

Untuk menghentikan ekstraksi ini menggunakan tolak ukur eigen value lebih dari 1. 
Tabel 4. Total Variance Explained

\begin{tabular}{|c|c|c|c|c|c|c|c|c|c|}
\hline \multirow[b]{2}{*}{$\begin{array}{l}\text { Compon } \\
\text { ent }\end{array}$} & \multicolumn{3}{|c|}{ Initial Eigenvalues } & \multicolumn{3}{|c|}{$\begin{array}{c}\text { Extraction Sums of Squared } \\
\text { Loadings }\end{array}$} & \multicolumn{3}{|c|}{$\begin{array}{c}\text { Rotation Sums of Squared } \\
\text { Loadings }\end{array}$} \\
\hline & Total & $\begin{array}{l}\% \text { of } \\
\text { Variance }\end{array}$ & $\begin{array}{l}\text { Cumulati } \\
\text { ve } \%\end{array}$ & Total & $\begin{array}{l}\% \text { of } \\
\text { Variance }\end{array}$ & $\begin{array}{l}\text { Cumulati } \\
\text { ve } \%\end{array}$ & Total & $\begin{array}{l}\% \text { of } \\
\text { Variance }\end{array}$ & $\begin{array}{l}\text { Cumulati } \\
\text { v } \\
\text { e \% }\end{array}$ \\
\hline 1 & 6.672 & 15.885 & 15.885 & 6.672 & 15.885 & 15.885 & 2.670 & 6.358 & 6.358 \\
\hline 2 & 2.173 & 5.173 & 21.058 & 2.173 & 5.173 & 21.058 & 2.224 & 5.296 & 11.654 \\
\hline 3 & 2.111 & 5.026 & 26.085 & 2.111 & 5.026 & 26.085 & 2.017 & 4.801 & 16.455 \\
\hline 4 & 1.850 & 4.405 & 30.490 & 1.850 & 4.405 & 30.490 & 1.995 & 4.751 & 21.206 \\
\hline 5 & 1.681 & 4.002 & 34.492 & 1.681 & 4.002 & 34.492 & 1.864 & 4.437 & 25.644 \\
\hline 6 & 1.598 & 3.805 & 38.297 & 1.598 & 3.805 & 38.297 & 1.829 & 4.355 & 29.999 \\
\hline 7 & 1.471 & 3.502 & 41.798 & 1.471 & 3.502 & 41.798 & 1.758 & 4.186 & 34.185 \\
\hline 8 & 1.439 & 3.426 & 45.224 & 1.439 & 3.426 & 45.224 & 1.747 & 4.159 & 38.343 \\
\hline 9 & 1.429 & 3.402 & 48.626 & 1.429 & 3.402 & 48.626 & 1.710 & 4.071 & 42.414 \\
\hline 10 & 1.271 & 3.026 & 51.652 & 1.271 & 3.026 & 51.652 & 1.704 & 4.057 & 46.471 \\
\hline 11 & 1.228 & 2.923 & 54.574 & 1.228 & 2.923 & 54.574 & 1.670 & 3.975 & 50.446 \\
\hline 12 & 1.192 & 2.839 & 57.413 & 1.192 & 2.839 & 57.413 & 1.657 & 3.945 & 54.392 \\
\hline 13 & 1.144 & 2.725 & 60.137 & 1.144 & 2.725 & 60.137 & 1.571 & 3.740 & 58.132 \\
\hline 14 & 1.103 & 2.627 & 62.765 & 1.103 & 2.627 & 62.765 & 1.557 & 3.708 & 61.840 \\
\hline 15 & 1.042 & 2.482 & 65.246 & 1.042 & 2.482 & 65.246 & 1.431 & 3.407 & 65.246 \\
\hline
\end{tabular}

Dari tabel diatas untuk menghentikan ekstraksi menggunakan tolak ukur eigenvalue nilai lebih dari satu ( $>1$ ) terdapat 15 faktor yang terbentuk dan nilai yang kurang dari 1 tidak digunakan atau tidak dipakai

c) Melakukan rotasi dari faktor yang terbentuk, tujuan dalam rotasi untuk memudahkan dalam interprestasi.

Hasil rotated component matrixa menunjukkan pengelompokan faktor yang membentuk ada 15 faktor baru yang terbentuk dan untuk niai loading dibawah 0,5 tidak digunakan atau tidak dimasukkan ke faktor yang terbentuk. Variabel yang telah di kelompokan dan bisa diberi nama untuk faktor baru atau pemberian nama faktor baru. Dari 15 faktor baru yang terbentuk terdiri dari 26 variabel yang mempunyai nilai diatas 0,5 dan 16 variabel nilainya dibawah 0,5. Didalam penelitian ini untuk pemberian nama faktor baru bersifat subyektif atau melihat nilai faktor loading yang terbesar dalam (Imam Ghozali, 2016:383).

\section{PEMBAHASAN}

1. Faktor satu yang mempengaruhi siswa dalam memilih sekolah di SMK Nasional Mojosari terdiri dari variabel sebagai berikut : a. Pilihan Jurusan dan Ekstrakulikuler dengan nilai loading 0,710, b. Status Terakreditasi A dengan nilai loading 0,733, c. Kemampuan Guru dengan nilai loading 0,653 . Untuk pemberian nama faktor baru peneliti berpedoman pada yang bersifat subyektif dalam pemberian nama, maka nama faktor tersebut 
diberi nama faktor Produk sekolah. Dapat disimpulkan dari faktor satu yang paling berpengaruh dalam pengambilan keputusan siswa memilih sekolah di SMK Nasional Mojosari adalah variabel Status terakreditasi A dengan nilai loading sebesar 0,733. Dengan nilai total varian (\% of variance) 15,885 dan nilai kumulatif (cumulative \%) 15,885.

2. Faktor dua yang mempengaruhi siswa dalam memilih sekolah di SMK Nasional Mojosari terdiri dari variabel sebagai berikut : a. Lokasi sekolah mudah diakses dengan nilai loading 0,770 , b. Berada di wilayah banyak sekolah dengan nilai loading 0,746 . Untuk pemberian nama faktor baru peneliti berpedoman pada yang bersifat subyektif dalam pemberian nama, maka nama faktor tersebut diberi nama faktor Lokasi. Dapat disimpulkan dari faktor dua yang paling berpengaruh dalam pengambilan keputusan siswa memilih sekolah di SMK Nasional Mojosari adalah variabel Lokasi sekolah mudah diakses dengan nilai loading sebesar 0,770. Dengan nilai total varian (\% of variance) 5,173 dan nilai kumulatif (cumulative \%) 21,058.

3. Faktor tiga yang mempengaruhi siswa dalam memilih sekolah di SMK Nasional Mojosari terdiri dari variabel sebagai berikut : a. Tempat aman dan nyaman dengan nilai loading 0,839 , b. Kebiasaan tidak diterima di sekolah negeri dengan nilai loading 0,896 . Untuk pemberian nama faktor baru peneliti berpedoman pada yang bersifat subyektif dalam pemberian nama, maka nama faktor tersebut diberi nama faktor Budaya. Dapat disimpulkan dari faktor tiga yang paling berpengaruh dalam pengambilan keputusan siswa memilih sekolah di SMK Nasional Mojosari adalah variabel Kebiasaan tidak diterma di sekolah negeri dengan nilai loading sebesar 0,896. Dengan nilai total varian (\% of variance) 5,026 dan nilai kumulatif (cumulative \%) 26,085.

4. Faktor empat yang mempengaruhi siswa dalam memilih sekolah di SMK Nasional Mojosari terdiri dari variabel sebagai berikut : a. Tempat bersih dengan nilai loading 0,703 , b. Ketersediaan mushollah dengan nilai loading 0,749, c. Ketersediaan 1 unit mobil dengan nilai loading 0,523. Untuk pemberian nama faktor baru peneliti berpedoman pada yang bersifat subyektif dalam pemberian nama, maka nama faktor tersebut diberi nama faktor Fasilitas. Dapat disimpulkan dari faktor empat yang paling berpengaruh dalam pengambilan keputusan siswa memilih sekolah di SMK Nasional Mojosari adalah variabel Ketersediaan mushollah dengan nilai loading sebesar 0,749 . Dengan nilai total varian (\% of variance) 4,405 dan nilai kumulatif (cumulative \%) 30,490.

5. Faktor lima yang mempengaruhi siswa dalam memilih sekolah di SMK Nasional Mojosari terdiri dari variabel sebagai berikut : a. Gambaran sekolah SMK Nasional Mojosari dengan nilai loading 0,740, b. Keyakinan diri dengan nilai loading 0,549. Untuk pemberian nama faktor baru peneliti berpedoman pada yang bersifat subyektif dalam pemberian nama, maka nama faktor tersebut diberi nama faktor Persepsi peran. Dapat disimpulkan dari faktor lima yang paling berpengaruh dalam pengambilan keputusan siswa memilih sekolah di SMK Nasional Mojosari adalah 
variabel Gambaran sekolah SMK Nasional Mojosari dengan nilai loading sebesar 0,740. Dengan nilai total varian (\% of variance) 4,002 dan nilai kumulatif (cumulative \%) 34,492.

6. Faktor enam yang mempengaruhi siswa dalam memilih sekolah di SMK Nasional Mojosari terdiri dari variabel sebagai berikut : a. Melalui sosial media youtube atau instagram dengan nilai loading 0,538 . b. Bekerjasama dengan perusahaan dan instansi perkantoran dengan nilai loading 0,741. Untuk pemberian nama faktor baru peneliti berpedoman pada yang bersifat subyektif dalam pemberian nama, maka nama faktor tersebut diberi nama faktor Promosi. Dapat disimpulkan dari faktor enam yang paling berpengaruh dalam pengambilan keputusan siswa memilih sekolah di SMK Nasional Mojosari adalah variabel Bekerjasama dengan perusahaan dan instansi perkantoran dengan nilai loading sebesar 0,741. Dengan nilai total varian (\% of variance) 3,805 dan nilai kumulatif (cumulative \%) 38,297.

7. Faktor tujuh yang mempengaruhi siswa dalam memilih sekolah di SMK Nasional Mojosari terdiri dari variabel sebagai berikut : a. Kebutuhan wawasan atau ilmu pengetahuan dengan nilai loading 0,796. Untuk pemberian nama faktor baru peneliti berpedoman pada yang bersifat subyektif dalam pemberian nama, maka nama faktor tersebut diberi nama faktor Motivasi. Dapat disimpulkan dari faktor tujuh yang paling berpengaruh dalam pengambilan keputusan siswa memilih sekolah di SMK Nasional Mojosari adalah variabel Kebutuhan wawasan atau ilmu pengetahuan dengan nilai loading sebesar 0,796. Dengan nilai total varian (\% of variance) 3,502 dan nilai kumulatif (cumulative \%) 41,798.

8. Faktor delapan yang mempengaruhi siswa dalam memilih sekolah di SMK Nasional Mojosari terdiri dari variabel sebagai berikut : a. Pemilihan ruang lab dengan nilai loading 0,646 , b. Rasa percaya diri dengan nilai loading 0,796 . Untuk pemberian nama faktor baru peneliti berpedoman pada yang bersifat subyektif dalam pemberian nama, maka nama faktor tersebut diberi nama faktor Lab yang representatif. Dapat disimpulkan dari faktor delapan yang paling berpengaruh dalam pengambilan keputusan siswa memilih sekolah di SMK Nasional Mojosari adalah variabel Rasa percaya diri dengan nilai loading sebesar 0,796. Dengan nilai total varian (\% of variance) 3,426 dan nilai kumulatif (cumulative \%) 45,224.

9. Faktor sembilan yang mempengaruhi siswa dalam memilih sekolah di SMK Nasional Mojosari terdiri dari variabel sebagai berikut : a. Ketersediaan lapangan olahraga dengan nilai loading 0,633, b. Kelompok alumni sekolah SMK Nasional Mojosari dengan nilai loading 0,617. Untuk pemberian nama faktor baru peneliti berpedoman pada yang bersifat subyektif dalam pemberian nama, maka nama faktor tersebut diberi nama faktor Sinergi sekolah dan alumni. Dapat disimpulkan dari faktor sembilan yang paling berpengaruh dalam pengambilan keputusan siswa memilih sekolah di SMK Nasional Mojosari adalah variabel Ketersediaan lapangan olahraga dengan nilai loading sebesar 0,633. Dengan nilai total varian (\% of variance) 3,402 dan nilai kumulatif (cumulative \%) 48,626. 
10. Faktor sepuluh yang mempengaruhi siswa dalam memilih sekolah di SMK Nasional Mojosari terdiri dari variabel sebagai berikut : a. Proses pembelajaran serius tapi santai dengan nilai loading 0,792. Untuk pemberian nama faktor baru peneliti berpedoman pada yang bersifat subyektif dalam pemberian nama, maka nama faktor tersebut diberi nama faktor Proses. Dapat disimpulkan dari faktor sepuluh yang paling berpengaruh dalam pengambilan keputusan siswa memilih sekolah di SMK Nasional Mojosari adalah variabel Proses pembelajaran serius tapi santai dengan nilai loading sebesar 0,792. Dengan nilai total varian (\% of variance) 3,026 dan nilai kumulatif (cumulative \%) 51,652.

11. Faktor sebelas yang mempengaruhi siswa dalam memilih sekolah di SMK Nasional Mojosari terdiri dari variabel sebagai berikut : a. Keluarga utama atau besar dengan nilai loading 0,812 , b. Kemudahan bergaul dengan nilai loading 0,631 . Untuk pemberian nama faktor baru peneliti berpedoman pada yang bersifat subyektif dalam pemberian nama, maka nama faktor tersebut diberi nama faktor Sosial. Dapat disimpulkan dari faktor sebelas yang paling berpengaruh dalam pengambilan keputusan siswa memilih sekolah di SMK Nasional Mojosari adalah variabel Keluarga dengan nilai loading sebesar 0,812. Dengan nilai total varian (\% of variance) 2,923 dan nilai kumulatif (cumulative \%) 54,574.

12. Faktor dua belas yang mempengaruhi siswa dalam memilih sekolah di SMK Nasional Mojosari terdiri dari variabel sebagai berikut : a. Kecekatan dengan nilai loading 0,727 . Untuk pemberian nama faktor baru peneliti berpedoman pada yang bersifat subyektif dalam pemberian nama, maka nama faktor tersebut diberi nama faktor Kecekatan. Dapat disimpulkan dari faktor dua belas yang paling berpengaruh dalam pengambilan keputusan siswa memilih sekolah di SMK Nasional Mojosari adalah variabel Kecekatan dengan nilai loading sebesar 0,727. Dengan nilai total varian (\% of variance) 2,839 dan nilai kumulatif (cumulative \%) 57,413.

13. Faktor tiga belas yang mempengaruhi siswa dalam memilih sekolah di SMK Nasional Mojosari terdiri dari variabel sebagai berikut : a. Pendapatan keluarga dengan nilai loading 0,754 . Untuk pemberian nama faktor baru peneliti berpedoman pada yang bersifat subyektif dalam pemberian nama, maka nama faktor tersebut diberi nama faktor Situasi ekonomi. Dapat disimpulkan dari faktor tiga belas yang paling berpengaruh dalam pengambilan keputusan siswa memilih sekolah di SMK Nasional Mojosari adalah variabel Pendapatan keluarga dengan nilai loading sebesar 0,754. Dengan nilai total varian (\% of variance) 2,725 dan nilai kumulatif (cumulative \%) 60,137.

14. Faktor empat belas yang mempengaruhi siswa dalam memilih sekolah di SMK Nasional Mojosari terdiri dari variabel sebagai berikut : a. Gratis biaya spp dan seragam sekolah 100 pendaftar pertama dengan nilai loading 0,744 . Untuk pemberian nama faktor baru peneliti berpedoman pada yang bersifat subyektif dalam pemberian nama, maka nama faktor tersebut diberi nama faktor Bonus. Dapat disimpulkan dari faktor empat belas yang paling berpengaruh dalam pengambilan keputusan siswa 
memilih sekolah di SMK Nasional Mojosari adalah variabel Gratis biaya spp dan seragam sekolah 100 pendaftar pertama dengan nilai loading sebesar 0,744. Dengan nilai total varian (\% of variance) 2,627 dan nilai kumulatif (cumulative \%) 62,765.

15. Faktor lima belas yang mempengaruhi siswa dalam memilih sekolah di SMK Nasional Mojosari terdiri dari variabel sebagai berikut : a. Beasiswa bagi siswa berprestasi dengan nilai loading 0,786 . Untuk pemberian nama faktor baru peneliti berpedoman pada yang bersifat subyektif dalam pemberian nama, maka nama faktor tersebut diberi nama faktor Beasiswa. Dapat disimpulkan dari faktor lima belas yang paling berpengaruh dalam pengambilan keputusan siswa memilih sekolah di SMK Nasional Mojosari adalah variabel Beasiswa bagi siswa berprestasi dengan nilai loading sebesar 0,786. Dengan nilai total varian (\% of variance) 2,482 dan nilai kumulatif

(cumulative \%) 65,246.

\section{KESIMPULAN}

Berdasarkan hasil analisis penelitian ini yang menggunakan metode analisis faktor dan pembahasan dapat disimpulkan bahwa faktor-faktor yang mempengaruhi siswa memilih sekolah di SMK Nasional Mojosari sebagai berikut:

1. Faktor satu, faktor Produk sekolah dengan nilai varian sebesar 15,885 yang terdiri dari variabel (Pilihan jurusan dan ekstrakulikuler dengan nilai loading 0,710), (Status terakreditasi A dengan loading 0,733) dan (Kemampuan guru dengan niali loading 0,653).

2. Faktor dua, faktor Lokasi dengan nilai varian sebesar 5,173 yang terdiri dari variabel (Lokasi sekolah mudah di akses dengan loading 0,770) dan (Berada di wilayah banyak sekolah dengan loading 0,746).

3. Faktor tiga, faktor Budaya dengan nilai varian sebesar 5,026 terdiri dari variabel (Tempat aman dan nyaman dengan loading 0,839) dan (Kebiasaan tidak diterima di sekolah negeri dengan loading 0,896).

4. Faktor empat, faktor Fasilitas dengan nilai varian sebesar 4,405 yang terdiri dari variabel (Tempat bersih dengan loading 0,703), (Ketersediaan mushollah dengan loading 0,749) dan (Ketersediaan 1 unit mobil dengan loading 0,523).

5. Faktor lima, faktor Persepsi peran dengan nilai varian sebesar 4,002 yang terdiri dari variabel (Gambaran sekolah SMK Nasional Mojosari dengan loading 0,740) dan (Keyakinan diri dengan loading 0,549).

6. Faktor enam, faktor Promosi dengan nilai varian sebesar 3,805 yang terdiri dari variabel (Melalui sosial media youtube atau instagram dengan loading 0,538) dan (Bekerjasama dengan perusahaan dan instansi perkantoran dengan loading 0,741).

7. Faktor tujuh, faktor Motivasi dengan nilai varian sebesar 3,502 yang terdiri dari variabel (Kebutuhan wawasan atau ilmu pengetahuan dengan loading 0,796). 
8. Faktor delapan, faktor lab yang representatif dengan nilai varian sebesar 3,426 yang terdiri dari variabel (Pemilihan ruang lab dengan loading 0,646 ) dan (Rasa percaya diri dengan loading 0,796 ).

9. Faktor sembilan, faktor Sinergi sekolah dan alumni dengan nilai varian sebesar 3,402 yang terdiri dari variabel (Ketersediaan lapangan olahraga dengan loading 0,633) dan (Kelompok alumni SMK Nasional Mojosari dengan loading 0,617).

10. Faktor sepuluh, faktor Proses dengan nilai varian sebesar 3,026 yang terdiri dari variabel (Proses pembelajaran serius tapi santai dengan loading 0,792).

11. Faktor sebelas, faktor Sosial dengan nilai varian sebesar 2,923 yang terdiri dari variabel (Keluarga utama atau besar sekolah dengan loading 0,812) dan (Kemudahan bergaul dengan loading 0,631).

12. Faktor dua belas, faktor Kecekatan dengan nilai varian sebesar 2,839 yang terdiri dari variabel (Kecekatan dengan loading 0,727).

13. Faktor tiga belas, faktor Situasi ekonomi dengan nilai varian sebesar 2,725 yang terdiri dari variabel (Pendapatan keluarga dengan loading 0,754).

14. Faktor empat belas, faktor Bonus dengan nilai varian sebesar 2,627 yang terdiri dari variabel (Gratis biaya spp dan seragam sekolah 100 pendaftar pertama dengan loading 0,744).

15. Faktor lima belas, faktor Beasiswa dengan nilai varian sebesar 2,482 yang terdiri dari variabel (Beasiswa bagi siswa berprestasi dengan loading 0,786).

Dari ke lima belas faktor terbentuk yang paling berpengaruh terhadap siswa dalam memilih sekolah di SMK Nasional Mojosari adalah faktor Produk sekolah dengan nilai varian sebesar 15,885 .

\section{SARAN}

1. Kepada pihak sekolah SMK Nasional Mojosari disarankan tetap dipertahankan untuk promosi secara berkalanya. Untuk piilihan jurusan bisa ditambah lagi dengan menambah jurusan yang akan diambil siswa baru seperti multimedia. Untuk bonus siswa 100 pendaftar pertama bisa ditambah lagi kuota yang mendapat bonus untuk menarik siswa baru agar semakin banyak kedepannya.

2. Untuk penelitian selanjutnya diharapkan dapat menambah faktor dalam penelitianya dan mengembangakannya. Untuk jumlah sampel dalam penelitian selanjutnya bisa memakai 4, 5 atau 10 kali dari jumlah variabel penelitian. 


\section{DAFTAR PUSTAKA}

Alma, Buchari. (2013). Manajemen Dan Pemasaran Jasa. Cetakan Ke-10. Bandung: Alfabeta.

Ghozali, Imam. (2016). Aplikasi analisis multivariated dengan progam ibm spss 23 edisi 8. Semarang:Badan Penerbit Universitas Diponegoro.

Gunawan, Imam. (2017). Penngantar statistika inferensial. Jakarta: Rajawali Pers.

Hapsari Setyowardhani, Tengku Ezni Balqiah. 2014. Perilaku Konsumen. Cetakan 8: Edisi 1.Tangerang Selatan: Universitas Terbuka.

Hurriyati, Ratih. (2015). Bauran Pemasaran Dan Loyalitas Konsumen. Cetakan Ke-04. Bandung: Alfabeta.

Kotler, P dan K. L. Keller Amstrong. 2014. Manajemen Pemasaran. Edisi 13. Jilid I. Penerbit Erlangga. Jakarta. dan G, Armstrong. 2012. Principle ofMarketing. Edisi 14 Pearson Prentice Hall. New Jersey.

Lupiyadi, Rambat. (2014). Pemasaran jasa. Cetakan ke-11, edisi 1. Tangerang Selatan: Universitas Terbuka.

Maholtra, K Naresh. (2006). Riset Pemasaran Pendekatan Terapan. Edisi 4. Jakarta : Indeks.

Moleong, L. 2014. Metodologi penelitian kualitatif. Bandung: Rosda karya.

Musfar, Tengku Firli. (2018). Bauran Pemasaran Pada Barang Dan Jasa. Cetakan Pertama. Riau: Universitas Riau.

Reza E, Nur Khisom. 2014. Judul Analisis Faktor Yang Mempengaruhi Keputusan Pembellian Online Shop 43 (Four Three) Di Kota Jember. Skripsi Progam Sarjana Ekonomi Manajemen. Progam Sarjana Ekonomi. Jember: Universitas Jember.

Sagita Isnia, Elanda. 2015. Analisis Faktor-Faktor Yang Mempengaruhi Penggunaan E-Money. Skripsi Progam Sarjana Ekonomi Manajemen. Progam Sarjana Ekonomi. Surabaya: Universitas Negeri Surabaya.

Sugiyono. (2016). Metode Penelitian Kuantitatif, Kualitatif, Dan R\&D. Cetakan Ke-23. Bandung: Alfabeta.

Wahyudi Abadi, Eka. 2015. Faktor-Faktor Yang Dipertimbangkankonsumen Dalam Mengambil Keputusan Membeli Produk Handphone Android. 
Skripsi Progam Sarjana Ekonomi Manajemen. Progam Sarjana Ekonomi. Mojokerto : Universitas Islam Majapahit.

Wardani, Andrianti Tri. 2015. Judul Analisis Faktor-Faktor Yang Mempengaruhi Partisipasi Anggota Dalam Pembelian Di Kopma Unesa. Skripsi Progam Sarjana Ekonomi Manajemen. Progam Sarjana Ekonomi. Surabaya : Universitas Negeri Surabaya. 